\title{
Pengaruh Jenis Bahan Pakaian Terhadap Respon Psikologi Manusia Pada Saat Berolahraga di Lingkungan Panas
}

\author{
Raudhatul Jannah ${ }^{1}$, Iskandarhasaduddin ${ }^{2}$, MohdIqbal ${ }^{3}$ \\ 1,2,3)Jurusan Magister Teknik Industri, Fakultas Teknik Universitas Syiah Kuala \\ Jln.SyechAbdul Rauf No.7 Darussalam Banda Aceh 23111 \\ Email: raudhatuljannahdarwin89@gmail.com
}

\begin{abstract}
ABSTRAK
Perpindahan panas (thermal) dan kelembaban/uap air melalui pakaian melibatkan proses penguapan, kondensasi, penyerapan dan desorpsi. Pakaian bertindak sebagai penghalang yang menghambat penguapan serta mengurangi kehilangan panas tubuh dengan mengurangi sirkulasi udara di dekat kulit, sehingga pakaian yang memiliki kemampuan penguapan yang baik akan menguntungkan pada saat melakukan berolahraga. Tujuan dari penelitian ini adalah mengetahui respon fisiologi dan psikologi manusia pada saat berolahraga di lingkungan panas. Penelitian dilakukan pada 4 orang laki-laki dengan memakai tiga jenis pakaian dengan bahan berbeda, yakni: $100 \%$ katun, $100 \%$ poliester dan kombinasi $75 \%$ poliester dan $25 \%$ katun pada kondisi temperatur di lingkungan $30^{\circ} \mathrm{C}$. Mereka berolahraga menggunakan treadmill dengan kecepatan $7 \mathrm{~km} / \mathrm{jam}$ untuk setiap jenis pakaian selama 30 menit, dimana setiap 10 menit melakukan treadmill kemudian istirahat selama 5 menit. Setelah itu, dilakukan proses recovery selama 30 menit sebanyak dua kali. Hasil penelitian menunjukan bahwa kemampuan absorbsi keringat pada saat exercise pada bahan pakaian $100 \%$ katun lebih tinggi dibandingkan bahan $100 \%$ poliester dan kombinasi $75 \%$ poliester dan $25 \%$ katun, sedangkan kemampuan evaporasi keringat ketika proses recovery, bahan pakaian $100 \%$ poliester lebih baik dibandingkan 2 jenis bahan lainnya, sehingga pada saat berolahraga, bahan $100 \%$ poliester cenderung lebih kering dibandingkan bahan $100 \%$ pakaian katun dan kombinasi $75 \%$ poliester dan $25 \%$ katun. Untuk respon psikologi, pada saat responden berolahraga menggunakan bahan pakaian katun, mereka merasakan badan lebih terasa panas, basah dan sangat berkeringat.
\end{abstract}

Kata kunci: Respon fisiologi, Respon psikologi, Katun, Poliester, Treadmill

\begin{abstract}
The transfer of heat (thermal) and moisture/moisture through clothing involves the process of evaporation, condensation, absorption and desorption. Clothing acts as a barrier that inhibits evaporation and reduces body heat loss by reducing air circulation near the skin, so clothing that has good evaporation ability will be beneficial when exercising. The purpose of this study was to determine the response of human physiology and psychology when applying in a hot environment. The survey conducted on four men using three types of clothing with different materials, namely: $100 \%$ cotton, $100 \%$ polyester and a combination of $75 \%$ polyester and $25 \%$ cotton.
\end{abstract}

UNITEK Vol 12 No.1 Januari - Juni 2019 | p-ISSN 2089-3957 | e-ISSN 2580-2585 
Under conditions of temperature in the environment of $30^{\circ} \mathrm{C}$. They exercise using a treadmill with a speed of $7 \mathrm{~km} / \mathrm{h}$ for each type of clothing for 30 minutes, where every 10 minutes on a treadmill then rest for 5 minutes. After that, the recovery process is carried out for 30 minutes twice. The results showed that the absorption capacity of sweat during exercise on 100\% cotton was higher than 100\% polyester and a combination of $75 \%$ polyester and $25 \%$ cotton, while sweat evaporation ability during the recovery process, $100 \%$ polyester clothing material was better than 2 other types of equipment, so that when exercising, $100 \%$ polyester material tends to be drier than $100 \%$ cotton and $75 \%$ polyester and $25 \%$ cotton. For the psychological response, when the respondents exercise d using cotton clothing, they felt the body feel hot, wet and very sweaty.

Keywords: Physiological response, Psychological Response, Cotton, Polyester, Treadmill

\section{Pendahuluan}

Pakaian adalah salah satu produk yang mempengaruhi kondisi panas tubuh pada saat berolahraga. Dalam iklim panas pakaian berfungsi untuk menjaga tubuh dari paparan sinar matahari atau berbagai dampak lainnya, sedangkan di iklim dingin sifat insulasi termal pakaian penting untuk menjaga tubuh agar tetap selalu hangat. Pakaian bertindak sebagai penghalang yang menghambat penguapan serta mengurangi kehilangan panas tubuh dengan mengurangi sirkulasi udara di dekat kulit (Pascoe dkk., 2009), sehingga pakaian yang memiliki kemampuan penguapan yang baik akan menguntungkan pada saat melakukan olahraga. Kemampuan pakaian dalam menyerap keringat dan penguapan tergantung dari permeabilitas udara dan uap air dari pakaian tersebut. Permeabilitas udara adalah porositas atau kemudahan udara melewati materi. Permeabilitas udara menentukan faktor-faktor seperti perlawanan angin pada kain, hambatan udara kain parasut, dan efektivitas berbagai jenis filter udara. Hal ini juga mempengaruhi kehangatan atau kesejukan kain. Sedangkan permeabilitas uap air adalah ukuran untuk breathability atau kemampuan tekstil untuk mentransfer kelembaban. Sehingga semakin tinggi permeabilitas uap air suatu pakaian maka semakin tinggi pula kemampuannya dalam menyerap keringat. Kondisi ini menguntungkan saat olahraga karena dengan kemampuan menyerap keringat maka dapat menurunkan core dan skin temperature dengan cepat. Untuk meminimalisir terjadinya heat strain maka diperlukan tindakan preventif seperti perbaikan lingkungan kerja atau perbaikan pakaian yang digunakan oleh pekerja yang dapat melindungi diri dari lingkungan panas (Muflichatun, 2006).

Tabel 1 menunjukkan bahwa perbandingan permeabilitas udara dan uap air antara pakaian jenis poliester dan katun. Dimana pakaian jenis poliester memiliki permeabilitas udara lebih tinggi dibandingkan katun namun sebaliknya katun memiliki daya permeabilitas uap air yang lebih tinggi. Poliester merupakan jenis bahan pakaian yang sering digunakan dalam pembuatan pakaian olahraga, karena bahan pakaian ini dianggap mampu menguapkan keringat yang tinggi sedangkan kemampuan menyerap keringat yang rendah. Jenis bahan pakaian lain yang

UNITEK Vol 12 No.1 Januari - Juni 2019 | p-ISSN 2089-3957 | e-ISSN 2580-2585 
dianggap nyaman saat dipakai yaitu katun. Dimana kain katun merupakan salah satu jenis pakaian yang memiliki properti menyerap air yang baik, menyerap kelembaban dari kulit lebih efektif daripada bahan pakain serat sintetis sehingga dengan tingginya kemampuan jenis pakaian ini dalam menyerap air diharapkan dapat menurunkan suhu tubuh saat berolahraga (Dai dkk., 2008).

Untuk mempertahankan keseimbangan termal pada tubuh maka ditentukan oleh sifat transfer uap dari pakaian dan lingkungan dan proses produksi panas metabolik (Saphiro, 1982). Saat berolahraga terjadi proses produksi panas metabolik. Produksi panas metabolik yang dihasilkan sebanding dengan jumlah kerja yang dilakukan, sedangkan perbedaan suhu tubuh inti (Tcore) manusia yang berolahraga pada intensitas latihan disebabkan oleh perbedaan efisiensi pembuangan panas. Faktorfaktor ini ditinjau efeknya pada peningkatan biofisik atau penekanan berkeringat, dan modifikasi dari hubungan antara tingkat keringat lokal dan Tcore (derajat C). Sehingga para atlet disarankan untuk mengoptimalkan faktor-faktor yang meningkatkan, dan menghilangkan faktor-faktor yang mengurangi, omset dan respon berkeringat (Armstrong dkk.,1998).

Menurut (Rahayu, dkk., 2008) menyatakan bahwa pakaian olahraga merupakan salah satu hal penting saat melakukan aktivitas fisik berolahraga. Tidak hanya kenyamanan dari pemakai, tetapi hendaknya pakaian dapat menunjang aktivitas fisik pemakainnya. Temperatur tubuh juga merupakan salah satu alat pengaturan suhu tubuh manusia. Penelitian ini menggunakan dua jenis baju olahraga yaitu pakaian olahraga terbuka dan tertutup. Sehingga penelitian memperoleh hasil pakaian olahraga baik terbuka ataupun tertutup memberikan pengaruh terhadap temperatur tubuh, denyut nadi dan pemulihan asam laktat. Pengaruh pakaian olahraga tertutup lebih tinggi daripada pakaian olahraga terbuka.

Tabel 1. Perbandingan permeabilitas udara dan air jenis kain katun dan poliester

\begin{tabular}{|l|c|c|}
\hline \multicolumn{1}{|c|}{ Jenis Pakaian } & $\begin{array}{c}\text { Air Permeability } \\
\text { (mm/s) }\end{array}$ & $\begin{array}{c}\text { Water Vapor Permeability } \\
\text { (g/m2) }\end{array}$ \\
\cline { 1 - 1 } Katun 94\% & 327.1 & 6134.2 \\
\cline { 1 - 2 } Elasten 6\% & 528.1 & 5793.8 \\
\hline Poliester 93\% & & \\
\hline Elasten 7\% & & \\
\hline
\end{tabular}

(Sumber : Ha, dkk 1999)

Dari kelebihan-kelebihan yang dimiliki oleh kedua jenis bahan pakaian tersebut, maka perlu dilakukan penelitian jenis pakaian mana yang lebih nyaman untuk dipakai pada saat berolahraga. Penelitian ini akan dilakukan di daerah dataran rendah kabupaten Pidie. Dengan pertimbangan letak geografis. Permasalahan yang akan diteliti adalah jenis pakaian yang lebih nyaman untuk dipakai oleh atlet sepakbola pada saat berolahraga di suhu panas.

UNITEK Vol 12 No.1 Januari - Juni 2019 | p-ISSN 2089-3957 | e-ISSN 2580-2585 


\section{Metode Penelitian}

Secara umum, penelitian ini akan dilakukan dalam beberapa tahapan. Tahapan penelitian yang akan dilakukan digambarkan oleh diagram alir pada Gambar 1.

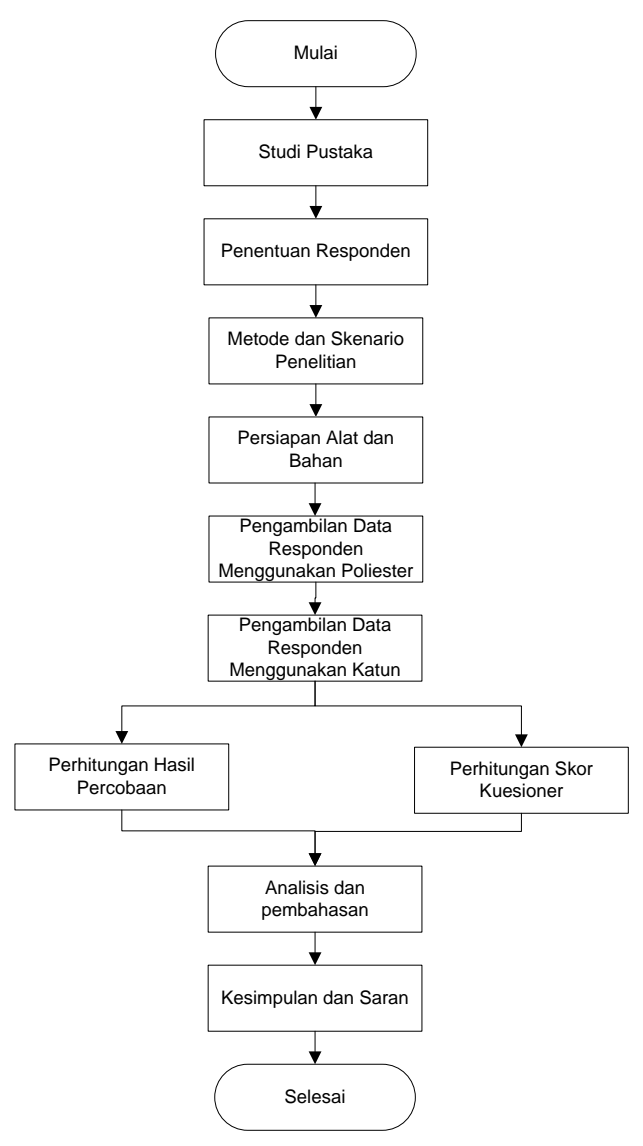

Gambar 1. Diagram alir penelitian

Berdasarkan Gambar 1 penelitian ini memiliki kerangka sebagai berikut:

\section{Penentuan Responden (Objek Penelitian)}

Responden dari penelitian ini adalah pria berumur 20-30 tahun berjumlah 4 orang, tidak merokok, memiliki kriteria BMI normal, sehat dan aktif berolahraga.

Tabel 2. Data fisiologi responden

\begin{tabular}{|c|l|c|c|c|}
\hline No & \multicolumn{1}{|c|}{ Nama Responden } & $\begin{array}{c}\text { Tinggi Badan } \\
(\mathbf{c m})\end{array}$ & $\begin{array}{c}\text { Berat Badan } \\
(\mathbf{k g})\end{array}$ & $\begin{array}{c}\text { Usia } \\
\text { (Thn) }\end{array}$ \\
\hline 1 & Muhammad Kurniawan & 160 & 63 & 26 \\
\hline 2 & Muhammad Deka Saputra & 162 & 65 & 25 \\
\hline 3 & IsmulArif & 158 & 60 & 27 \\
\hline 4 & Mariyadi & 156 & 59 & 29 \\
\hline
\end{tabular}

(Sumber : Jannah, 2016)

UNITEK Vol 12 No.1 Januari - Juni 2019 | p-ISSN 2089-3957 | e-ISSN 2580-2585 


\section{Metode dan Skenario Penelitian}

Penelitian ini dilakukan dengan beberapa tahapan, yaitu:

a. Setiap responden diminta untuk exercise menggunakan pakaian katun dan poliester menggunakan treadmill

b. Latihan dilakukan pada waktu dan hari yang sama dengan dua sesi yang berbeda, yaitu terpisah jarak satu minggu

c. Pengujian dilakukan di sebuah bilik dengan $\mathrm{Ta}=30^{\circ} \mathrm{C}, \mathrm{RH}=60 \%$

d. Responden menggunakan sepatu, kaus kaki, celana pendek yang sama untuk kedua jenis pakaian

e. Pakaian untuk eksperimen sudah ada di bilik, 2 jam sebelum dilakukan eksperimen

f. Latihan dilakukan dengan treadmill dengan kecepatan $7 \mathrm{~km} / \mathrm{jam}$

g. Berat badan responden ditimbang terlebih dahulu, kemudian istirahat 10 menit diruang yang bersuhu $21^{\circ} \mathrm{C}$, setelah itu masuk bilik yang sudah disiapkan. HR dan berat pakaian diukur, lalu pakaian dipakai setelah itu istirahat 10 menit

h. Selama istirahat subjective thermal sensation, clothing wettedness sensation dan shivering/sweating

i. Subject rating perception, HR dan berat pakaian diukur setelah latihan, yaitu ketika istirahat 5 menit dan ketika RT 30 dan RT 60

j. Berat badan tanpa pakaian dan HR juga diukur ketika proses recovery.

\section{Persiapan Alat dan Bahan}

Alat dan bahan yang digunakan dalam penelitian ini adalah:
1. Treadmill
2. Alat ukur heart rate
3. Timbangan badan
4. Pakaian berbahan katun dan poliester
5. Stopwatch
6. Laptop
7. Software SPSS

\section{Pengambilan Data Responden Menggunakan Poliester}

Pengambilan data responden pertama dilakukan dengan pakaian berbahan poliester. Responden diminta untuk treadmill selama 30 menit dengan istirahat setiap 10 menit selama 5 menit, kemudian recovery dengan total waktu 60 menit. Setelah responden melakukan treadmill selama 10 menit dan recovery selama 60 menit, responden diminta untuk mengisi kuesioner untuk melihat tingkat kebasahan pakaian, kondisi tubuh apakah menggigil atau berkeringat dan sensasi apa yang dirasakan selama treadmill pada ruangan bersuhu $30^{\circ} \mathrm{C}$.

\section{Pengambilan Data Responden Menggunakan Katun}

Pengambilan data ini dilakukan 1 minggu setelah pengambilan data menggunakan poliester. Alur penelitian yang dilakukan sama dengan pengambilan data responden ketika menggunakan poliester.

UNITEK Vol 12 No.1 Januari - Juni 2019 | p-ISSN 2089-3957 | e-ISSN 2580-2585 


\section{Perhitungan Hasil Percobaan}

Setelah semua percobaan menggunakan bahan pakaian poliester dan katun dilakukan, tahap selanjutnya adalah melakukan perhitungan hasil percobaan yaitu menghitung perubahan heart rate, perubahan berat badan dan berat pakaian selama exercise dan recovery.

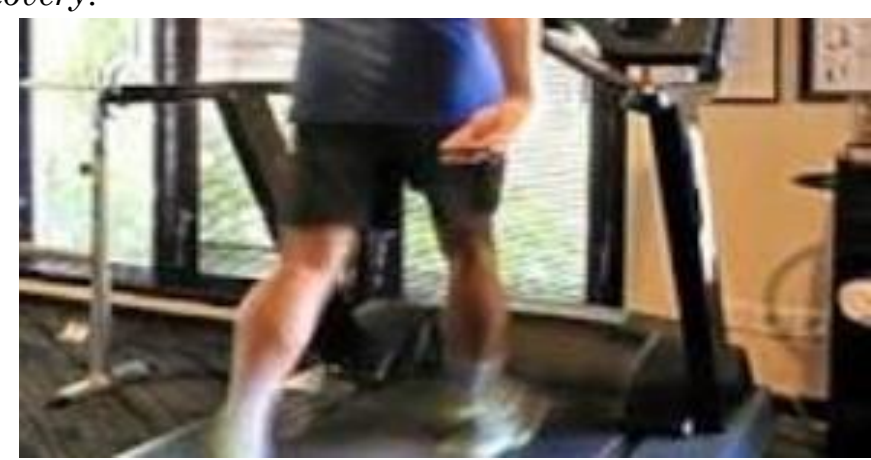

Gambar 2. Responden no.3 sedang berjalan di treadmill

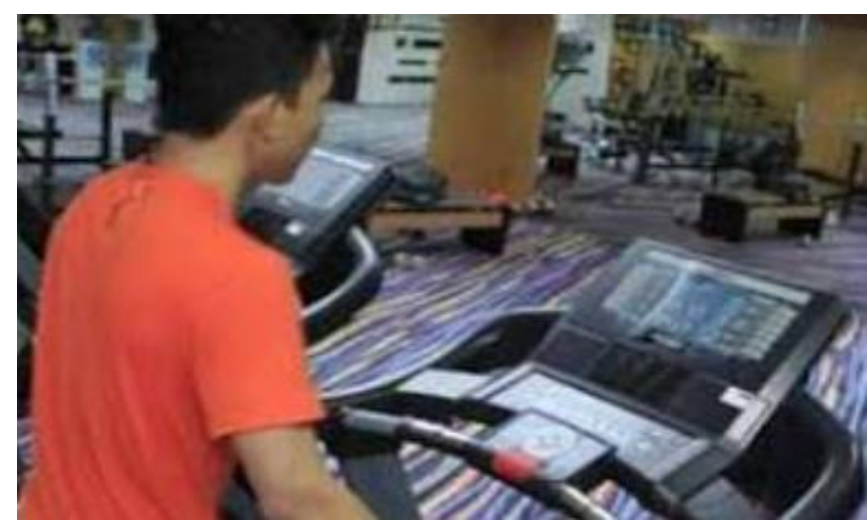

Gambar 3. Responden no.1 membaca jumlah heart rate

\section{Perhitungan Skor Kuesioner}

Tahap ini adalah menghitung hasil kuesioner terkait dengan tingkat kebasahan pakaian, sensasi yang dirasakan responden selama exercise dan recovery, dan kondisi tubuh apakah menggigil atau berkeringat dengan membuat persentase dari keseluruhan responden di setiap exercise dan recovery. Untuk memperoleh data mengenai respon psikologi melaui kuisoner, maka responden diminta untuk mengisi kuisoner sesuai dengan yang dirasakannya (Brazaitis dkk, 2010). Daftar pertanyaan pada kuisoner seperti yang ditunjukkan oleh Tabel 3.

UNITEK Vol 12 No.1 Januari - Juni 2019 | p-ISSN 2089-3957 | e-ISSN 2580-2585 
Tabel 3. Form kuisoner psikologi responden

\begin{tabular}{|l|l|}
\hline Sensation rate & \multicolumn{1}{|c|}{ Thermal Sensation } \\
\hline & Very cold \\
\hline & Cold \\
\hline & Cool \\
\hline & Slightly Cool \\
\hline & Neutral \\
\hline & Slightly Warm \\
\hline & Warm \\
\hline & Hot \\
\hline
\end{tabular}

Data yang telah dihitung kemudian dilakukan analisa berdasarkan perubahan heart rate, berat badan dan pakaian. Secara keseluruhan, dilakukan analisa perubahan respon fisiologi dan psikologi responden selama exercise dan recovery yang diperoleh pada saat pengujian langsung dan skor dari kuesioner. Tahapan ini berupa kesimpulan dari penelitian yang telah dilakukan dan saran untuk penelitian selanjutnya. Berdasarkan tabel sebelumnya dalam penelitian ini juga menampilkan beberapa gambar responden yang sedang melakukan kegiatan.

\section{Hasil dan Pembahasan}

Berdasarkan pengumpulan data maka penelitian ini menghasilkan beberapa data yang ditunjukkan dengan gambar dan grafik. Antara lain data yang diperoleh adalah mengukur energy expenditure dan dapat menganalisis pengaruh energy expenditure terhadap kenyamanan responden yang berolahraga dengan menggunakan 3 jenis pakaian dilingkungan panas. Perbedaan Heart rate melakukan tiga latihan dengan menggunakan 3 jenis pakaian ditunjukkan oleh Gambar 4.

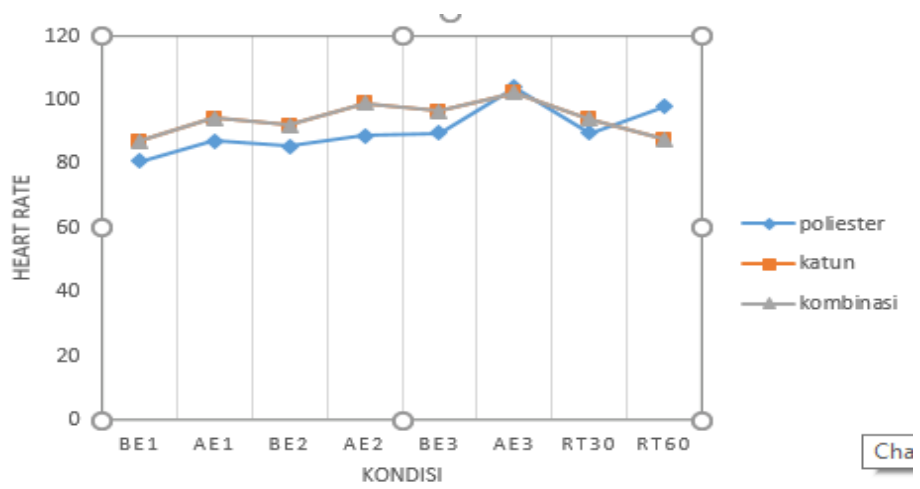

Keterangan:

Gambar 4. Grafik perbandingan heart rate

$\mathrm{BE}=$ Before exercise (sebelum latihan)

$\mathrm{AE}=$ After exercise (setelah latihan)

Gambar 4 menunjukan bahwa heart rate responden ketika menggunakan pakaian $100 \%$ katun dan kombinasi poliester $75 \%$ dan $25 \%$ katun berimpit dan tidak ada

UNITEK Vol 12 No.1 Januari - Juni 2019 | p-ISSN 2089-3957 | e-ISSN 2580-2585 
perbedaaan yang signifikan jika dibandingkan dengan bahan pakaian $100 \%$ poliester. Hal ini disebabkan oleh responden yang dipilih merupakan orang yang aktif dalam berolahraga sehingga heart rate mereka cenderung stabil walaupun memakai pakaian dengan jenis bahan yang berbeda.

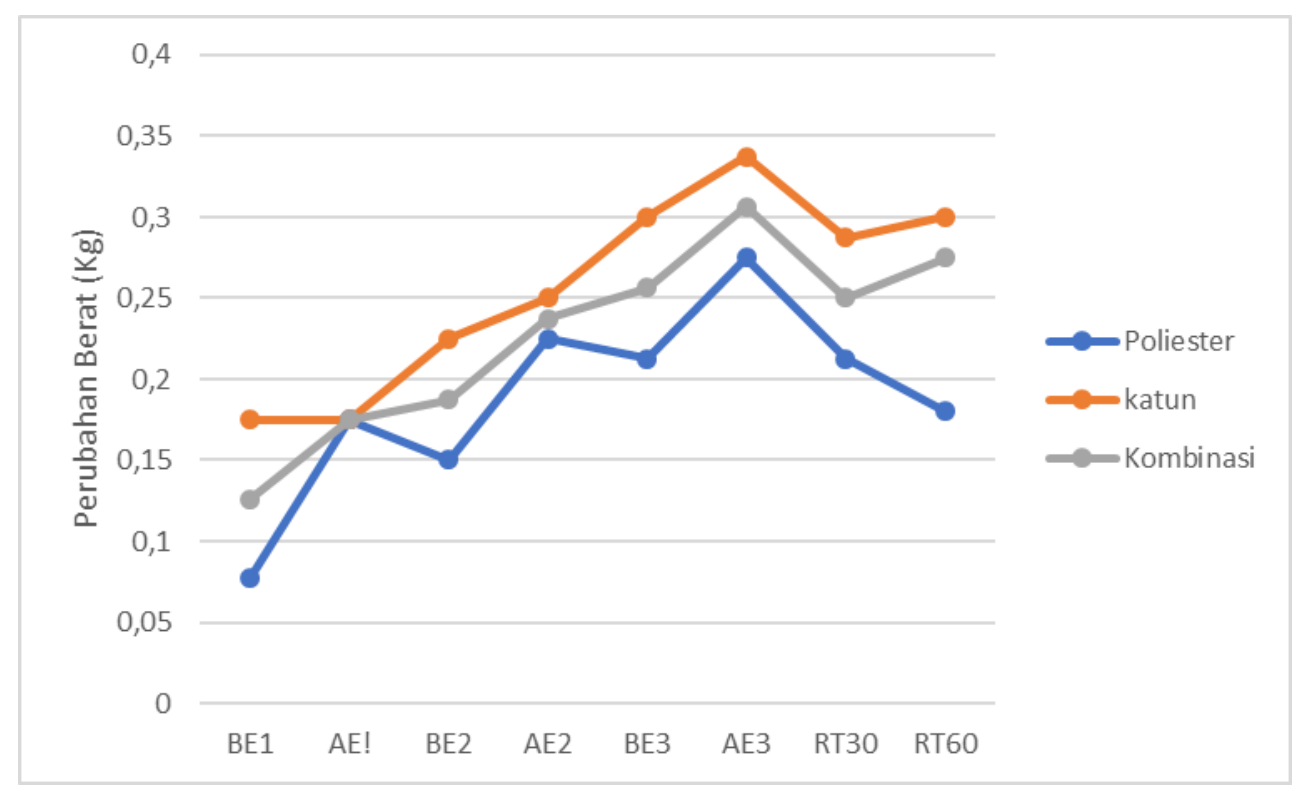

Gambar 5. Perbedaan berat pakaian selama exercise dan recovery

Gambar 5 memperlihatkan bahwa bahan pakaian jenis 100\% katun cenderung lebih berat karena bahan pakaian ini cepat dalam menyerap keringat. Hal ini disebabkan oleh permeabilitas uap air yang rendah, selain itu, bahan 100\% katun memiliki serat kain yang lebih rapat sehingga kemampuan menyerap air lebih baik dibandingkan bahan pakaian $100 \%$ poliester dan kombinasi $75 \%$ polyester dan $25 \%$ katun. Sedangkan pada $100 \%$ poliester berat pakaian mengalami kenaikan pada setiap exercise tetapi mengalami penurunan pada waktu istirahat.

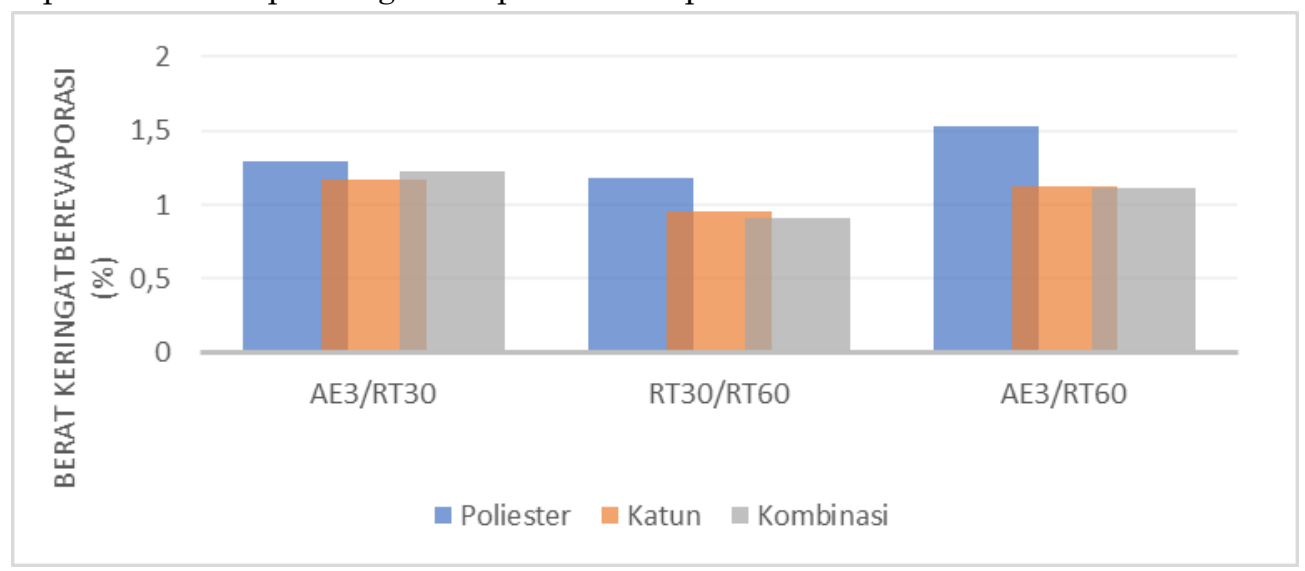

Gambar 6. Persentase perubahan berat pakaian selama recovery

UNITEK Vol 12 No.1 Januari - Juni 2019 | p-ISSN 2089-3957 | e-ISSN 2580-2585 
Gambar 6 menunjukkan bahwa terlihat bahwa pakaian jenis poliester lebih cepat dalam proses penguapan keringat. Dimana pada saat recovery selama 60 menit, bahan $100 \%$ poliester mampu menguapkan keringat sebanyak $15 \%$, sedangkan bahan $100 \%$ katun dan kombinasi $75 \%$ polyester dan $25 \%$ katun hanya mampu menguapkan keringat dibawah $10 \%$. Hasil ini sesuai dengan pernyataan Poliester merupakan jenis bahan pakaian yang sering digunakan dalam pembuatan pakaian olahraga, karena bahan pakaian ini dianggap mampu menguapkan keringat yang tinggi dan kemampuan dalam menyerap keringat yang rendah (Dai dkk.,2008). Perbedaan Konsumsi Energi (Energy Expenditure) yang dihasilkan oleh atlet pada saat berolahraga dengan waktu beristirahat yang ditunjukkan oleh Gambar 7.

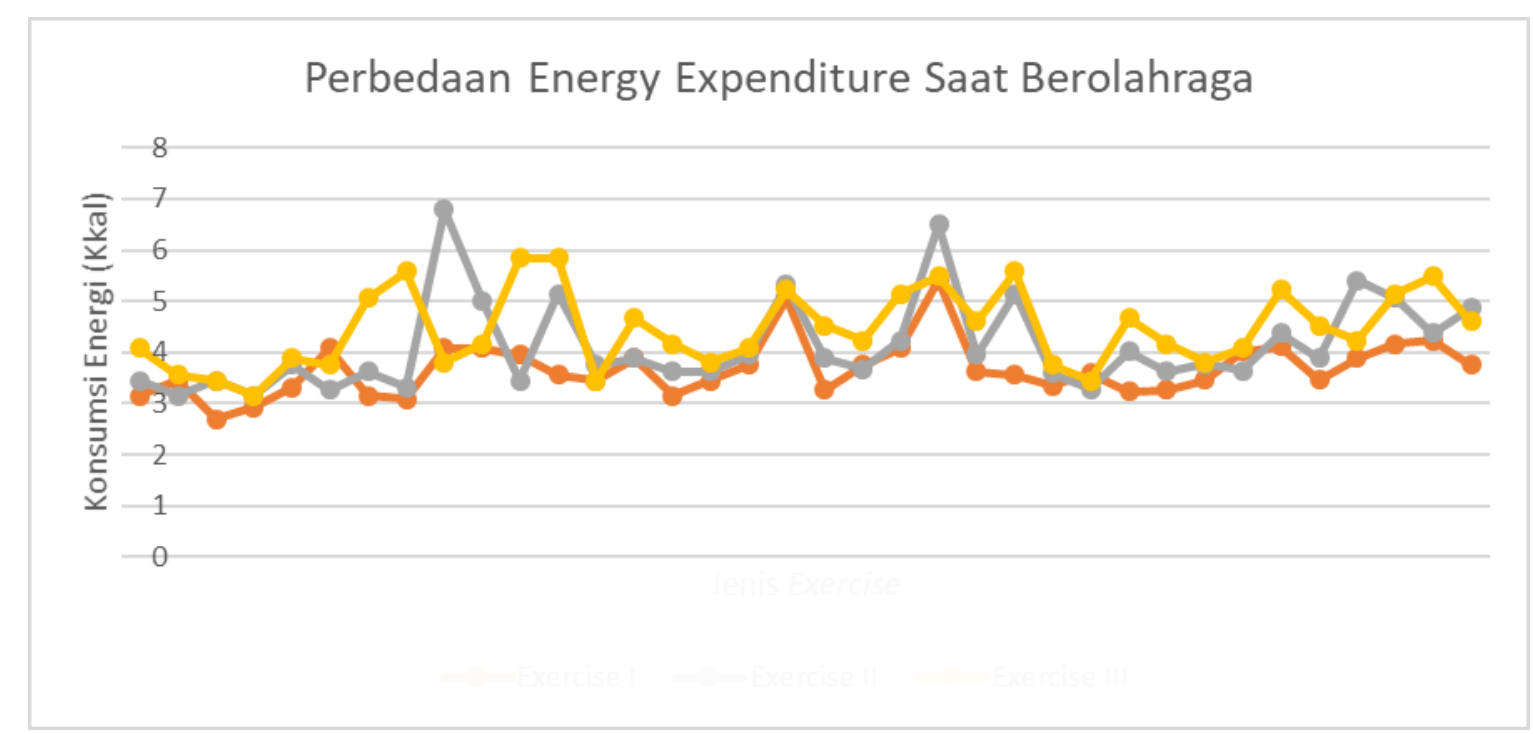

Gambar 7. Grafik perubahan energy expenditure selama berolahraga

Gambar 7 bahwa perubahan energy expenditure selama berolahraga yang terbesar di dominasi oleh jenis pakaian $100 \%$ katun yang ditunjukkan oleh warna abu-abu. Sedangkan bahan $100 \%$ polyester dan kombinasi $75 \%$ polyester dan $25 \%$ katun berada di antaranya yang ditunjukkan oleh warna kuning. Berdasarkan perhitungan tingkat konsumsi energi yang ditunjukkan oleh garafik 7, maka jenis aktivitas berolahraga dengan menggunnakn 3 pakaian dengan jenis bahan yang berbeda komposisinya tergolong ke dalam pekerjaan Moderate (Sanders, 2010).

UNITEK Vol 12 No.1 Januari - Juni 2019 | p-ISSN 2089-3957 | e-ISSN 2580-2585 


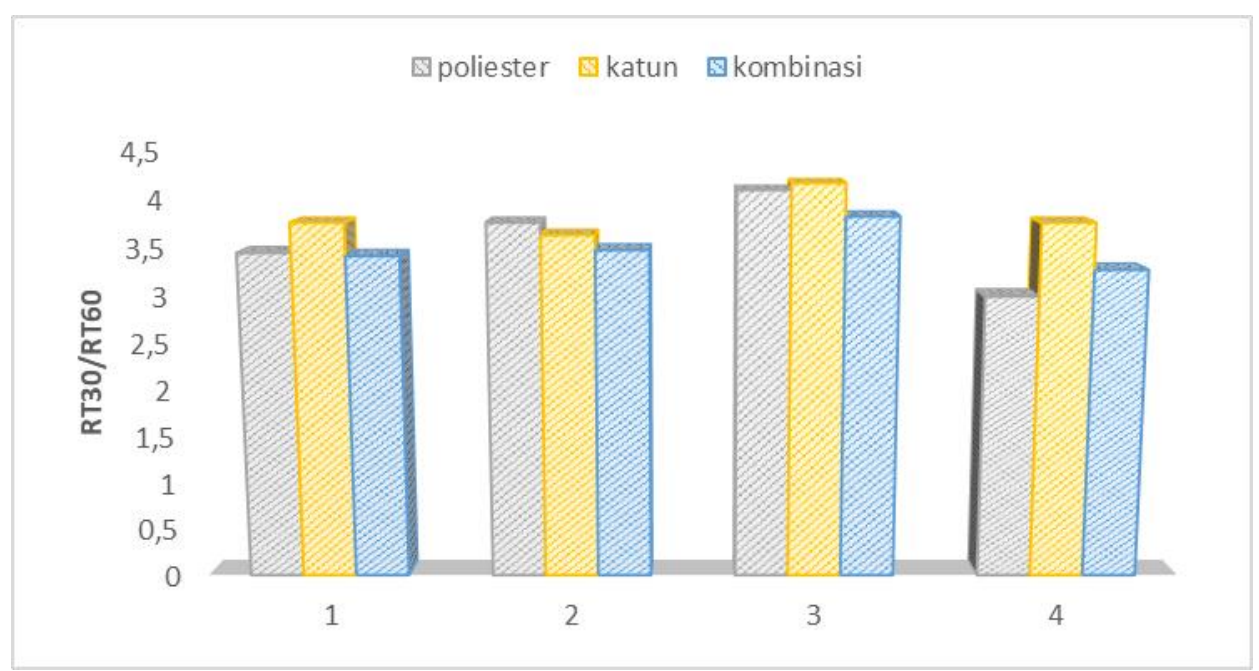

Gambar 8. Grafik perubahan energy expenditure selama beristirahat

\section{Keterangan:}

1: Latihan pertama

2: Latihan kedua

3: Latihan ketiga

4: Recovery.

Gambar 8 memperlihatkan bahwa konsumsi energi yang besar dari ketiga exercise ditunjukkan oleh pakaian berbahan katun. Berdasarkan konsumsi energi selama beristirahat maka aktivitas ini digolongkan ke dalam pekerjaan Light dimana konsumsi energi terletak anatara 1200-2400 Kkal/8 Jam dan denyut jantung yang berdetak/menit antara 60-100. Perubahan konsumsi energi dapat menghasilkan pengelompokkan jenis pekerjaan termasuk ke dalam kategorinya masing-masing. Analisis Respon Psikologi meliputi: a. Thermal Sensation merupakan kepuasan alami oleh manusia yang menerima suatu keadaan thermal, keadaan ini dialami baik secara sadar maupun tidak sadar. Gambar 9 menunjukkan kondisi thermal sensation yang berbeda antar jenis bahan pakaian.

UNITEK Vol 12 No.1 Januari - Juni 2019 | p-ISSN 2089-3957 | e-ISSN 2580-2585 


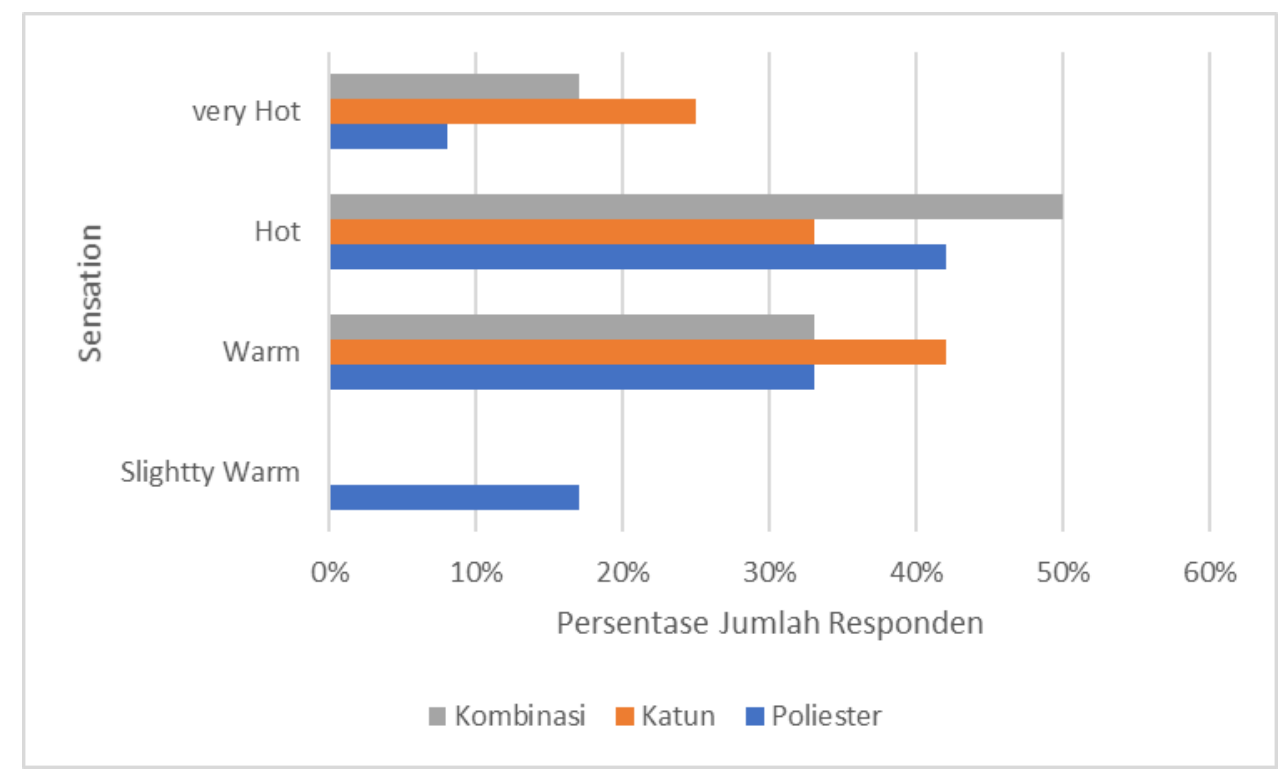

Gambar 10. Thermal sensation katun, poliester dan kombinasi

Gambar 10 menunjukkan bahwa thermal sensation yang dirasakan responden pada kondisi "hot" mengalami perbedaan yang signifikan. Hal ini disebabkan oleh tingginya daya serap dan rendahnya kemampuan evaporasi keringat pada pakaian katun. Ketika tubuh manusia kelebihan panas akibat berada pada lingkungan yang panas, maka mekanisme termoregulasi yang dilakukan adalah dengan vasodilasi yakni pembuluh darah akan melebar dan darah mengalir mendekati kulit kemudian melepaskan panas melalui kulit. B. Clothing Wettedness Sensation yang diperoleh dari hasil penelitian ditunjukkan oleh Gambar 11.

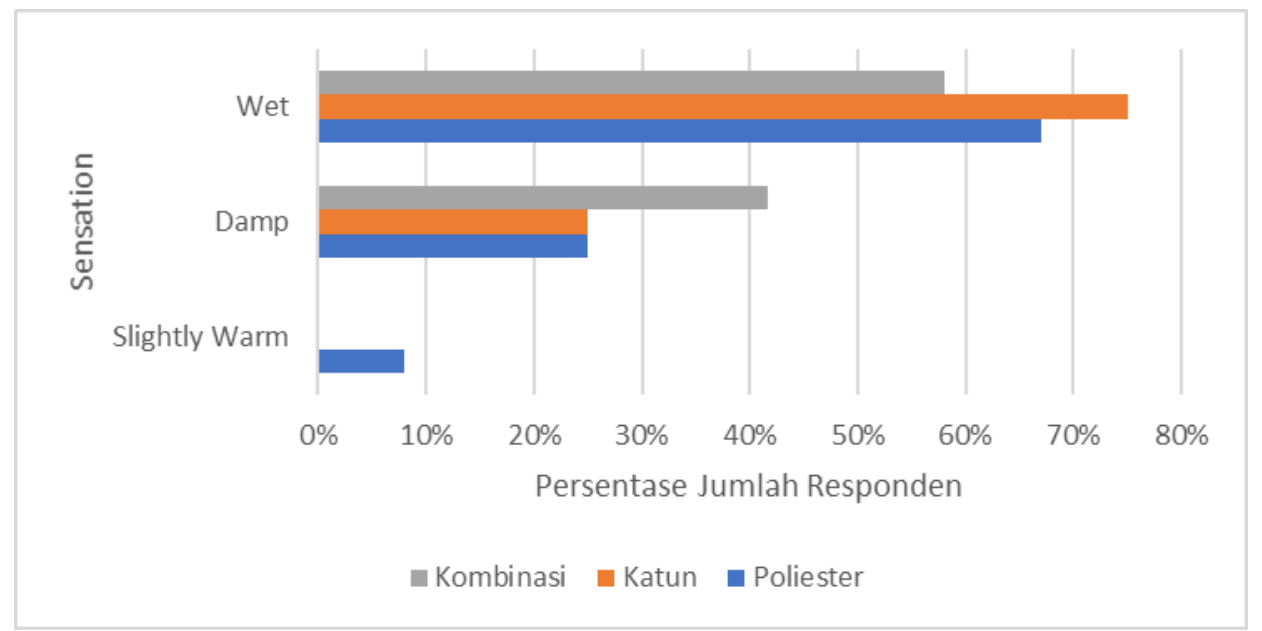

Gambar 11. Clothing Wettedness Sensation Katun, Poliester dan Kombinasi

Gambar 11 menunjukkan tingkat kebasahan pakaian yang digunakan oleh responden. Hasil yang diperoleh adalahpakaian berbahan katun lebih banyak mengeluarkan keringat, sehingga pakaianakan terasa lebih basah. Hal ini dikarenakan katun merupakan salah satu jenis pakaian yang memiliki properti

UNITEK Vol 12 No.1 Januari - Juni 2019 | p-ISSN 2089-3957 | e-ISSN 2580-2585 
menyerap air yang baik, menyerap kelembaban dari kulit lebih efektif daripada bahan pakain serat sintetis sehingga dengan tingginya kemampuan jenis pakaian ini dalam menyerap air diharapkan dapat menurunkan suhu tubuh saat berolahraga (Dai dkk., 2008). C. Shivering/Sweating Sensation yang diperoleh dari hasil penelitian ditunjukkan oleh Gambar 12.

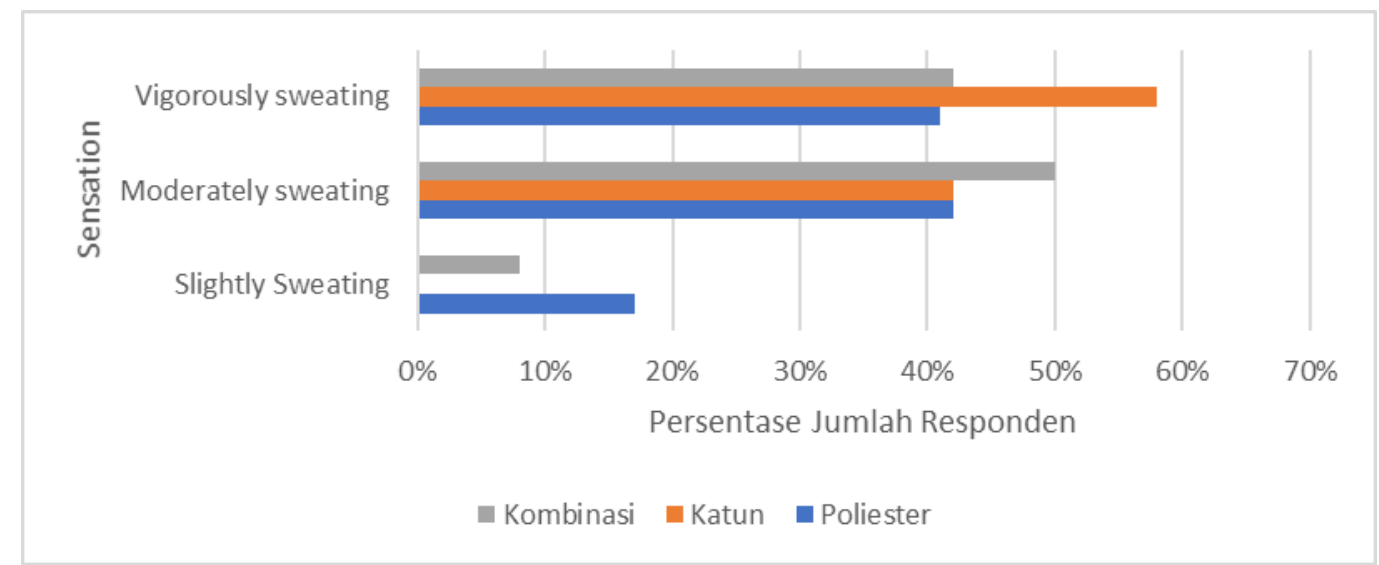

Gambar 12. Shivering/sweat sensation katun, poliester dan kombinasi

Gambar 12 menunjukkan jumlah keringat yang dikeluarkan responden setelah melakukan exercise s. Hasil yang diperoleh adalah pakaian berbahan katun akan lebih besar memicu responden untuk mengeluarkan keringat. Hasil yang diperoleh adalahpakaian berbahan katun lebih banyak mengeluarkan keringat, sehingga pakaianakan terasa lebih basah. Hal ini dikarenakan katun merupakan salah satu jenis pakaian yang memiliki properti menyerap air yang baik, menyerap kelembaban dari kulit lebih efektif daripada bahan pakain serat sintetis sehingga dengan tingginya kemampuan jenis pakaian ini dalam menyerap air diharapkan dapat menurunkan suhu tubuh saat berolahraga (Dai dkk., 2008).

\section{Simpulan}

Simpulan yang didapatkan dari penelitian adalah pakaian berbahan 100\% poliester merupakan bahan pakaian yang mampu memberikan respon fisiologi yaitu denyut jantung rata-rata pada menit ke-0 dengan ketiga exercise yaitu $81 \mathrm{bpm}, 85.5$ bpm, dan 89,75 bpm. Denyut jantung rata-rata pada menit ke-5 dengan ketiga exercise yaitu $87,25 \mathrm{bpm}, 88,75 \mathrm{bpm}$, dan $104 \mathrm{bpm}$. Denyut jantung rata-rata pada menit ke-10 dengan ketiga exercise yaitu 95,5 bpm, $110 \mathrm{bpm}$, dan 108,25 bpm. Pakaian berbahan $100 \%$ katun merupakan bahan pakaian yang mampu memberikan respon fisiologi yaitu denyut jantung rata-rata pada menit ke-0 dengan ketiga exercise yaitu $87,25 \mathrm{bpm}, 92,25 \mathrm{bpm}$, dan $96,5 \mathrm{bpm}$. Denyut jantung rata-rata pada menit ke-5 dengan ketiga exercise yaitu 94,25 bpm, 99 bpm, dan 102,25 bpm. Denyut jantung rata-rata pada menit ke-10 dengan ketiga exercise yaitu 99,25 bpm, 130,75 bpm, dan 108,25 bpm. Pakaian berbahan kombinasi 75\% poliester dan 25\% katun merupakan bahan pakaian yang mampu memberikan respon fisiologi yaitu denyut

UNITEK Vol 12 No.1 Januari - Juni 2019 | p-ISSN 2089-3957 | e-ISSN 2580-2585 
jantung rata-rata pada menit ke-0 dengan ketiga exercise yaitu $87 \mathrm{bpm}, 91 \mathrm{bpm}$, dan $92 \mathrm{bpm}$. Denyut jantung rata-rata pada menit ke-5 dengan ketiga exercise yaitu 93 bpm, 96 bpm, dan 52 bpm. Denyut jantung rata-rata pada menit ke-10 dengan ketiga exercise yaitu 97 bpm, 109 bpm, dan 54 bpm.

\section{Daftar Pustaka}

Armstong, EL., \& Maresh, CM. (1998). Effects of Training, Environment, and Host Factors on Sweating Response to Exercise. International Journal of Sports Medicine.

Astutik, R. (2008). Pengaruh Berpakaian Olahraga Tertutup dan Berpakaian Olahraga Terbuka Terhadap Peningkatan Temperatur Tubuh, Peningkatan Denyut Nadi, Penurunan Kadar Asam Laktat dan Kelincahan Akibat Latihan Fisik (Penelitian Eksperimental).Jakarta: Universitas Airlangga.

Brazaitis, M., Kamandulis, S., Skurvydas, A., \& Daniusevciute. (2010). The Effect of Two Kinds of T-Shirts on Physiological and Psychological Thermal Responses During Exercise and Recovery. Applied Ergonomics 42, 46-51.

Dai, X.Q., Imamura, R., Liu, G.L., \& Zhou, F.P. (2008). Effect of Moisture Transport on Microclimate Under T-shirt. Europan Journal of Applied Physiology 104(2), 337-340.

Ha, M., Tokura, H., Yanai, Y., Moriyama, T., \& Tsuchiya, N. (1999). Combined Effects Of Fabric Air Permeability And Moisture Absorption On Clothing Microclimate And Subjective Sensation During Intermittent Exercise at $27^{\circ} \mathrm{C}$. Ergonomics 42(7), 964-979.

Muflichatun. (2006). Hubungan Antara Tekanan Panas, Denyut Nadi, dan Produktivitas Kerja Pada Pekerja Pandai besi Paguyuban Wesi Aji Donorejo Batang, Skripsi, Jurusan Ilmu Kesehatan Masyarakat, Universitas Negeri Semarang, Semarang.

Pascoe, D.D., Bellingar, T.A., McCluskey, B.S. (2009). Clothing and exercise: II. Influence of Clothing During Exercise /Work In Environment Extremes.

Sanders, Mark S \& McCormick, Ernest J. (2010), Human Factor in Engineering and Design, New York: McGraw-Hill.Inc.

Shapiro Y, Pandolf KB, Goldman RF. 1982. Predicting sweat loss response toexercise, environment and clothing. Eur J Appl Physiol Occup Physiol. 48:83-9.

UNITEK Vol 12 No.1 Januari - Juni 2019 | p-ISSN 2089-3957 | e-ISSN 2580-2585 